\title{
David Oliver: Why shouldn't nurses be graduates?
}

\author{
David Oliver consultant in geriatrics and acute general medicine
}

Berkshire

The Daily Telegraph columnist Allison Pearson has set out her and her readers' suggestions for saving the NHS. ${ }^{12}$ Alongside a range of reactionary ideas, she trotted out a recurring and predictable trope, beloved of some commentators in sections of the press: "Too many nurses with degrees who say, 'I don't do sick."”2

This bizarre animus against graduate nurses has given rise to a stereotype that such nurses are "too posh to wash." ${ }^{44}$ This is often accompanied by wistful yearnings for a golden age of authoritarian matrons who could spot dust bionically. Letters follow from pre-degree nurses asserting their generation's superior values or from older doctors agreeing fulsomely. ${ }^{5}$

Where's the empirical evidence that higher education makes people too grand to deliver hands-on practical care? Or that a degree somehow removes their compassion?

Some people prefer anecdotes to data-and I'll tell you mine. I work every day with graduate nurses from the UK, Ireland, Spain, Portugal, India, and several Caribbean and African countries. When I can't find them, it's invariably because they're behind a curtain giving practical help, moving and handling patients, not running away in horror from bodily fluids.

The treatment and technologies we can offer patients have grown exponentially, and so has the potential for risks and harms

I don't expect that we'll see media commentators saying that paramedics, occupational therapists, physiotherapists, or speech therapists shouldn't require degree level training. Yet they're in patient facing roles and generally deliver care that's as person centred, caring, and holistic as it gets. Their empathy hasn't been destroyed by going to university. What's uniquely different about nurses?

The business of healthcare in 2017 is infinitely more complex than when I started out. Patients' age, acuity, and range of comorbidities have increased. Pressure, pace, and turnover are higher. The treatment and technologies we can offer patients have grown exponentially, and so has the potential for risks and harms.
In turn, practitioners-including nurses-surely need strong educational underpinnings that include supervised "learning on the job" but go well beyond. Nurses now take on a whole range of advanced independent practice roles that are vital to services and require qualifications.

Yet NHS England's " 6 Cs" framework for nursing mentions "care, compassion, commitment, courage, and communication"-with "competence" seemingly an afterthought. ${ }^{6}$ Surely, we want all healthcare staff to have these qualities as a basic starting point.

But this alone isn't sufficient: delivering modern healthcare requires broader scientific, sociological, and technical knowledge and skills, not a narrow focus on practical tasks. The clincher lies in research evidence showing that, throughout Europe, patient mortality is lower the higher the proportion of graduate nurses in the team. ${ }^{7}$

Nursing seems to be the only profession where people argue that too much education is the cause of problems.

Competing interests: See www.bmj.com/about-bmj/freelancecontributors/david-oliver.

Provenance and peer review: Commissioned; not externally peer reviewed.

Follow David on Twitter, @mancunianmedic

1 Pearson A. The NHS is a national disgrace-here's my 10-point plan to save it. Daily Telegraph 10 Jan 2017. www.telegraph.co.uk/women/health/nhs-national-disgrace-10point-plan-save/.

2 Pearson A. It's time to fix the NHS, Mr Hunt. Telegraph readers have had some bright ideas ... Daily Telegraph 17 Jan 2017. www.telegraph.co.uk/women/health/time-fix-nhsmr-hunt-telegraph-readers-have-had-bright-ideas/.

3 Chapman J, Martin D. Nurses told, "you're not too posh to wash a patient": minister orders student nurses back to basics to improve compassion in NHS. Daily Mail 25 March 2013. www.dailymail.co.uk/news/article-2299085/Youre-posh-wash-patient-Minister-ordersstudent-nurses-basics-improve-compassion-NHS.html.

4 Fletcher V. Degree nurses "could get too posh to wash." Daily Express 13 Nov 2009 www.express.co.uk/news/uk/140065/Degree-nurses-could-get-too-posh-to-wash.

5 Dalrymple T. Sorry, Florence-no degree, no job. Daily Telegraph 13 Nov 2009. www. telegraph.co.uk/education/universityeducation/6558948/Sorry-Florence.-No-degree-nojob.html.

6 England NHS. 6Cs. https://www.england.nhs.uk/leadingchange/leading-change-addingvalue/about/the-6cs/.

King's College School of Nursing. Degree educated nurses can reduce hospital deaths. 28 Feb 2014. www.kcl.ac.uk/nursing/newsevents/news/2014/degree-educated-nursescan-reduce-hospital-deaths.aspx. 
Published by the BMJ Publishing Group Limited. For permission to use (where not already granted under a licence) please go to http://group.bmj.com/group/rights-licensing/

permissions 